\title{
Oxidative Stress and Hypoxia Contribute to Alzheimer's Disease Pathogenesis: Two Sides of the Same Coin
}

\author{
Michela Guglielmotto, Elena Tamagno*, and Oliviero Danni \\ Department of Experimental Medicine and Oncology, University of Torino, Italy \\ E-mail: elena.tamagno@unito.it
}

Received May 22, 2009; Revised July 13, 2009; Accepted July 18, 2009; Published August 11, 2009

\begin{abstract}
While it is well established that stroke and cerebral hypoperfusion are risk factors for Alzheimer's disease (AD), the molecular link between ischemia/hypoxia and amyloid precursor protein (APP) processing has only been recently established. Here we review the role of the release of reactive oxygen species (ROS) by the mitochondrial electron chain in response to hypoxia, providing evidence that hypoxia fosters the amyloidogenic APP processing through a biphasic mechanism that up-regulates $\beta$-secretase activity, which involves an early release of ROS and an activation of HIF-1a.
\end{abstract}

KEYWORDS: Alzheimer's disease, hypoxia, oxidative stress, BACE1

\section{INTRODUCTION}

Alzheimer's disease (AD) is classified into two forms: sporadic late-onset $\mathrm{AD}$, which is correlated to aging, and rare familial early-onset $\mathrm{AD}$ (FAD), caused by gene mutations. The pathology of $\mathrm{AD}$ is defined by the presence of extracellular plaques composed by amyloid- $\beta$ (A $\beta$ ) fibrils, intracellular neurofibrillary tangles (NFTs) composed of hyperphosphorylated tau protein, and synaptic loss.

Central to the disease is the altered proteolytic processing of the A $\beta$ precursor protein (APP), resulting in overproduction and aggregation of neurotoxic forms of A $\beta$. APP is an integral membrane protein with a single, membrane-spanning domain; a large, extracellular N-terminus; and a shorter, cytoplasmic C-terminus. The amyloidogenic processing of APP involves two sequential cleavages operated by the $\beta$ - and $\gamma$-secretases at the $\mathrm{N}$ - and $\mathrm{C}$-termini of $\mathrm{A} \beta$.

The $\beta$-secretase (BACE1) cleaves APP at the beginning of the A $\beta$ sequence, generating an extracellular soluble fragment, called s $\beta$ APP, and an intracellular C-terminal end, termed C99. C99 is further cleaved within the membrane by the $\gamma$-secretase. The $\gamma$-cleavage produces $A \beta$ fragments of different length, predominantly $\mathrm{A} \beta 40$ and $\mathrm{A} \beta 42$.

The role of $\mathrm{A} \beta$ in the pathogenesis of $\mathrm{AD}$ is supported by two major clues. Aggregates of $\mathrm{A} \beta$ are neurotoxic and initiate a series of events, including the hyperphosphorylation of tau, which result in neuronal dysfunction and cell death[1]. APP gene overdosage as well as the gene mutations that cause FAD facilitate the accumulation of $A \beta 42$, increasing its production and aggregation[2,3,4]. The cause of modified APP processing and A $\beta 42$ accumulation in sporadic cases of AD is unclear, but is likely to include oxidative stress (OS). Thus, OS results from several cellular insults, such as hyperglycemia, 
glutamate, prion proteins, and calcium homeostasis perturbation[5,6,7,8,9], and our study strengthens the hypothesis that $\mathrm{OS}$ is a basic common pathway of $\mathrm{A} \beta$ accumulation, as effected by different $\mathrm{AD}$ risk factors .

\section{AB AND OS IN AD/AGING BRAIN}

OS increases with age through variations in reactive oxygen species (ROS) generation, ROS elimination, or both[10]. The free radical hypothesis of aging implies that accumulation of ROS results in damage of the major cell components: nucleus, mitochondrial DNA, membranes, and cytoplasmic proteins[11]. The imbalance between the generation of free radicals and antioxidants has been claimed as a cause of AD. The brain is particularly vulnerable to OS because of its high utilization of oxygen, increased levels of polyunsaturated fatty acids, and relatively low levels of antioxidants[12,13].

OS and $A \beta$ are linked to each other since $A \beta$ aggregation induces $O S$ in vivo and in vitro $[14,15,16]$, and oxidants increase the production of $\mathrm{A} \beta[17,18,19,20,21]$. Transition metals, $\mathrm{Cu}(\mathrm{II}), \mathrm{Zn}(\mathrm{II})$, and $\mathrm{Fe}(\mathrm{III})$, favor the neurotoxicity of $A \beta$ through their reduction, which produces hydrogen peroxide $\left(\mathrm{H}_{2} \mathrm{O}_{2}\right)[22]$. Using density functional theory calculations, it has been shown that the $A \beta$ residue Tyr-10 is a pivotal residue to drive the catalytic production of $\mathrm{H}_{2} \mathrm{O}_{2}$ by $\mathrm{A} \beta$ peptides in the presence of $\mathrm{Cu}$ (II). The phenoxy radical of Tyr-10 produced by the reaction with ROS causes neurotoxicity and results in the formation of dityrosine, which accelerates the aggregation of $A \beta$ peptides[23]. Another crucial $A \beta$ residue is Met-35; the substitution of Met-35 with cysteine resulted in no protein oxidation in C. elegans model[24]. Moreover, the inhibition of cytochrome c oxidase by $\mathrm{A} \beta 42$ involves the formation of a redox active methionine radical[25]. Lipid peroxidation induced by $A \beta$ peptides impairs the function of ATPases, glucose and glutamate transporters, and also GTP-binding proteins as the result of covalent modification of the proteins by the aldehydic end products, such as 4-hydroxynonenal (HNE) $[15,26]$.

Moreover, $\mathrm{A} \beta$ peptides favor $\mathrm{Ca}^{2+}$ influx into neurons by inducing membrane-associated OS, rendering neurons vulnerable to excitotoxicity and apoptosis[27].

On the other hand, OS may also be the cause of $\mathrm{A} \beta$ accumulation. Oxidant agents and oxidative products increase APP expression[28,29], and intracellular and secreted A $\beta$ levels in neuronal and nonneuronal cells[17,18,19,20,21,30]. We and others have shown that the expression and activity of BACE1 is increased by oxidants[21,31,32,33,34]. Moreover, there is a significant correlation of BACE1 activity with oxidative markers in sporadic AD brain tissue[35], in which a significant increase of BACE1 expression has been shown[36,37,38,39].

\section{HYPOXIA IN AD/AGING BRAIN}

It is well known that patients with stroke and cerebral infarction are at risk of $\mathrm{AD}[9]$. Hypoxia is a direct consequence of hypoperfusion, which plays a role in the $A \beta$ accumulation.

Oxygen homeostasis is essential for the development and functioning of an organism. Hypoxia inducible factor (HIF)- $1 \alpha$ is a molecule that regulates oxygen homeostasis[40]. HIF-1 $\alpha$ is a member of the basic helix-loop-helix transcription factor family, and the basic region of the protein binds specifically to the 5'-RCGTGb hypoxia-responsive element (HRE) in a gene promoter region. HIF-1 contains an oxygen-regulated expression subunit $\alpha$ (HIF-1 $\alpha$ ) and a constitutively expressed subunit $\beta$ (HIF-1 $\beta$ ) (Arnt). HIF-1 $\alpha$ protein, mediated by its oxygen-dependent degradation domain, is rapidly degraded through the ubiquitin-proteosome pathway under normoxic conditions with a half-life of $<5 \mathrm{~min}$, but is quite stable under hypoxic conditions. The oxygen-dependent degradation of HIF- $1 \alpha$ is a substrate for posttranslational modification by prolyl hydroxylases (PHDs), enzymes that hydroxylate HIF-1 $\alpha$. This hydroxylated form may be recognized by the E3 ubiquitin protein ligase, called the von Hippel-Lindau (pVHL) protein, which signals HIF-1 $\alpha$ for degradation[40,41,42,43,44] (Fig. 1). 

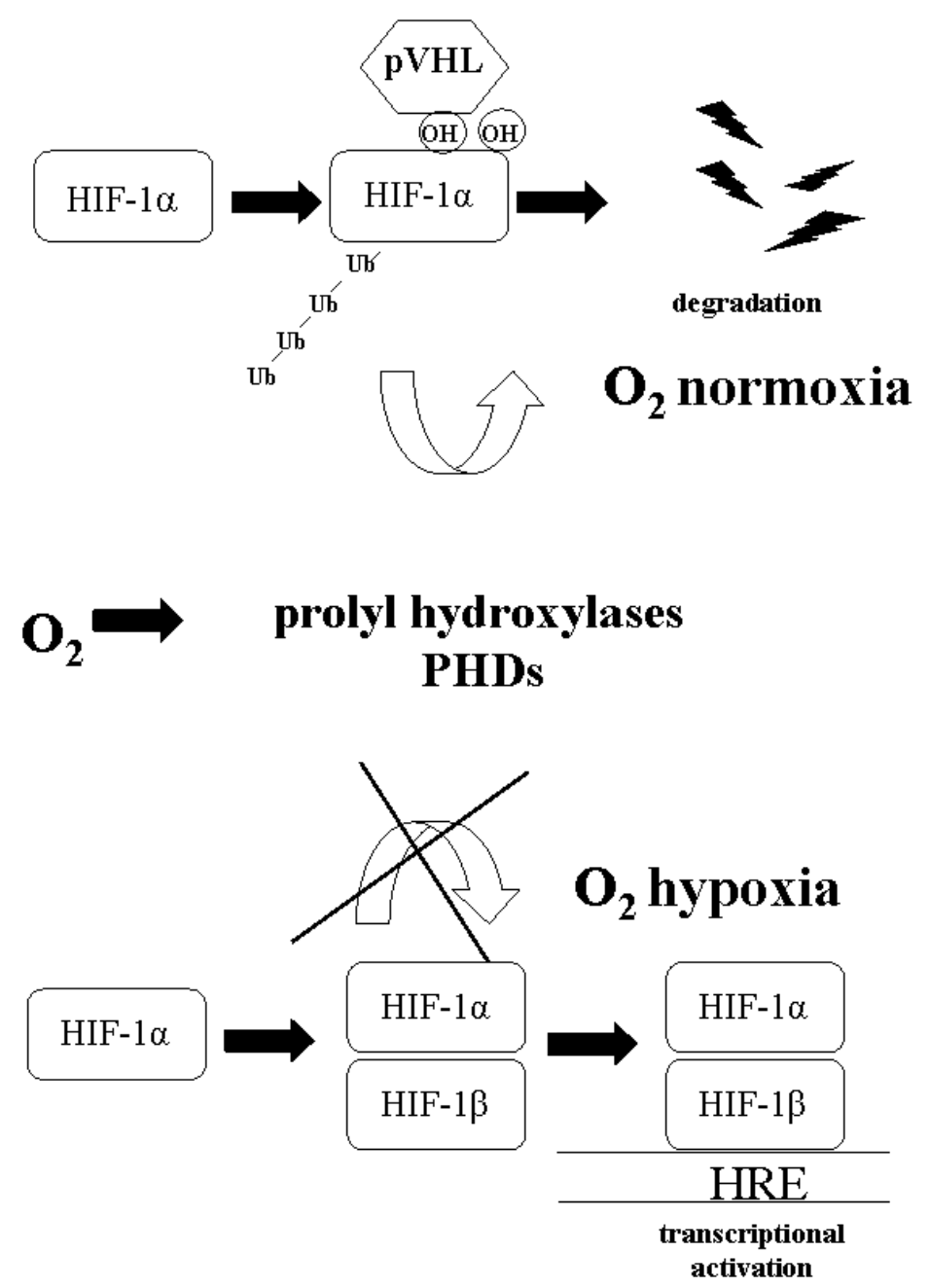

FIGURE 1. HIF-1 $\alpha$ pathway in normoxic and hypoxic conditions.

Prolonged and severe hypoxia can cause neuronal loss and memory impairment[45]. Recent studies have shown that a history of stroke can increase $\mathrm{AD}$ prevalence by approximately twofold in elderly patients[46,47]. The risk is higher when stroke is concomitant with atherosclerotic vascular risk factor[48]. Hypoxia is a direct consequence of hypoperfusion, a common vascular component among the $\mathrm{AD}$ risk factors.

Recently, it has been reported that hypoxia can alter APP processing, increasing the activity of the $\beta$ and $\gamma$-secretases. Sun and collaborators[49] showed that hypoxia significantly up-regulates BACE1 gene expression, resulting in increased $\beta$-secretase activity. Moreover, the same authors found that hypoxia increases $A \beta$ deposition and neuritic plaque formation, as well as memory deficit, in Swedish mutant APP transgenic mice. These data provide a molecular mechanistic link of vascular factors with AD.

More recently, sequence analysis and gel shift studies revealed binding of HIF-1 $\alpha$ to the BACE1 promoter. It has been shown that overexpression of HIF-1 $\alpha$ in neuronal cells increases BACE1 mRNA and protein levels, whereas down-regulation of HIF-1 $\alpha$ reduces the levels of BACE1[50]. Hypoxic conditions were also shown to increase the $\gamma$-secretase activity.

HIF-1 $\alpha$ binds to the anterior pharynx-defective phenotype (APH-1) promoter to up-regulate its expression. The activation of HIF-1 $\alpha$ induced by hypoxia increases the expression of APH-1 mRNA and protein, leading to an increased $\gamma$-cleavage of APP and Notch[51,52]. APH-1 is a key component of the $\gamma$ - 
secretase complex, together with presenilin, nicastrin (Nct), and presenilin enhancer (PEN) 2, a multimembrane-spanning protein that is required for the correct subcellular transport of Nct to the cell surface[53,54].

Collectively, these data showed that hypoxia increased the $\beta$ - and $\gamma$-secretase activities, which facilitate the abnormal cleavage of APP, resulting in the acceleration of A $\beta$ production and plaque formation both in vivo and in vitro.

\section{THE PARADOX OF INCREASED ROS DURING HYPOXIA}

Although it is generally accepted that intracellular ROS levels change during hypoxia, the direction in which this change occurs is still hotly debated.

Levels of intracellular ROS paradoxically increase under hypoxia[55,56,57,58,59]. Early theories proposed that NADPH oxidase might be an important ROS-generating cellular oxygen sensor since this multisubunit membrane-bound enzyme is expressed in tissues implicated in systemic hypoxic responses and affects cellular redox status depending on cellular oxygen concentrations[60,61] However, other studies did not support the involvement of NADPH in the hypoxic adaptive response[62]. Chandel et al.[55] suggested that mitochondria are the source of ROS involved in the hypoxic response. The electron transport chain, which is embedded in the inner membrane of mitochondria, consists of five multiprotein complexes. Complexes I and II oxidize the energy-rich molecules NADH and FADH ${ }_{2}$, respectively, and transfer the resulting electrons to ubiquinol, which carries them to complex III. Complex III, in turn, shuttles the electrons across the inner mitochondrial membrane to cytochrome $\mathrm{c}$, which carries them to complex IV. Complex IV uses the electrons to reduce oxygen to water. Along with carrying electrons, complexes I, II, and III generate ROS[63,64]. It is now accepted that hypoxia increases ROS via the transfer of electrons from ubisemiquinone to molecular oxygen at the Qo site of complex III of the mitochondrial transport chain[65].

The mitochondria-derived ROS are both necessary and sufficient to stabilize and activate HIF-1 $\alpha$.

It has been demonstrated that antioxidants reverse hypoxia-induced HIF-1 $\alpha$ activation[66,67]. Recent antitumorigenic effects of antioxidants have been attributed to the inhibition of HIF-1 $\alpha$-dependent events[68]. Moreover, the addition of oxidants, such as $\mathrm{H}_{2} \mathrm{O}_{2}$, induces HIF-1 $\alpha$ activity up-regulation in normoxia[69,70].

Mitochondrial ROS regulate HIF-1 $\alpha$ stability on hypoxia through different mechanisms. These most likely involve the PHDs, the oxidases involved in the post-translational modification that signals HIF- $1 \alpha$ for degradation[71,72]. Recent work showed that mitochondrial inhibitors, such as rotenone and myxothiazol, and the antioxidant MitoQ, maintain PHD activity in hypoxic cells[73]. This mechanism is supported by the fact that genetic removal of the JunD-dependent antioxidant pathway leads to increased HIF-1 $\alpha$ activation through decreased activity of the HIF PHDs[74,75]. Under hypoxic conditions, mitochondrial ROS can also activate signaling pathways upstream of HIF-1, such as the extracellular signal-regulated mitogen activated kinase (ERK) and the p38 stress-activated MAPK pathways. ERK2 phosphorylates HIF-1 $\alpha$ in vitro and in vivo, and increases its transcriptional activity[76,77,78].

Regulation of HIF-1 $\alpha$ stability and function under hypoxic conditions is also modulated by the phosphatidylinositol 3 kinase (PI3K)-protein kinase B (PKB/Akt) signaling pathway[79]. Several studies have shown that ROS generation can activate this pathway and lead to enhancement of HIF-1 $\alpha$ in cancer cells[80,81,82]. PKB/Akt has several targets, such as the forkhead transcription factor 4 (FOXO4), the glycogen synthase kinase $3 \beta$ (GSK3 $\beta$ ), the oncoprotein human double minute 2 (HDM2), and tuberin (TSC2), a key component of the mTOR (mammalian target of rapamacyn) pathway. Although there is no evidence for direct phosphorylation of HIF-1 $\alpha$ by the PKB/Akt pathway, all the above-mentioned downstream effectors of the pathway influence HIF-1 $\alpha$ activity (Fig. 2). 


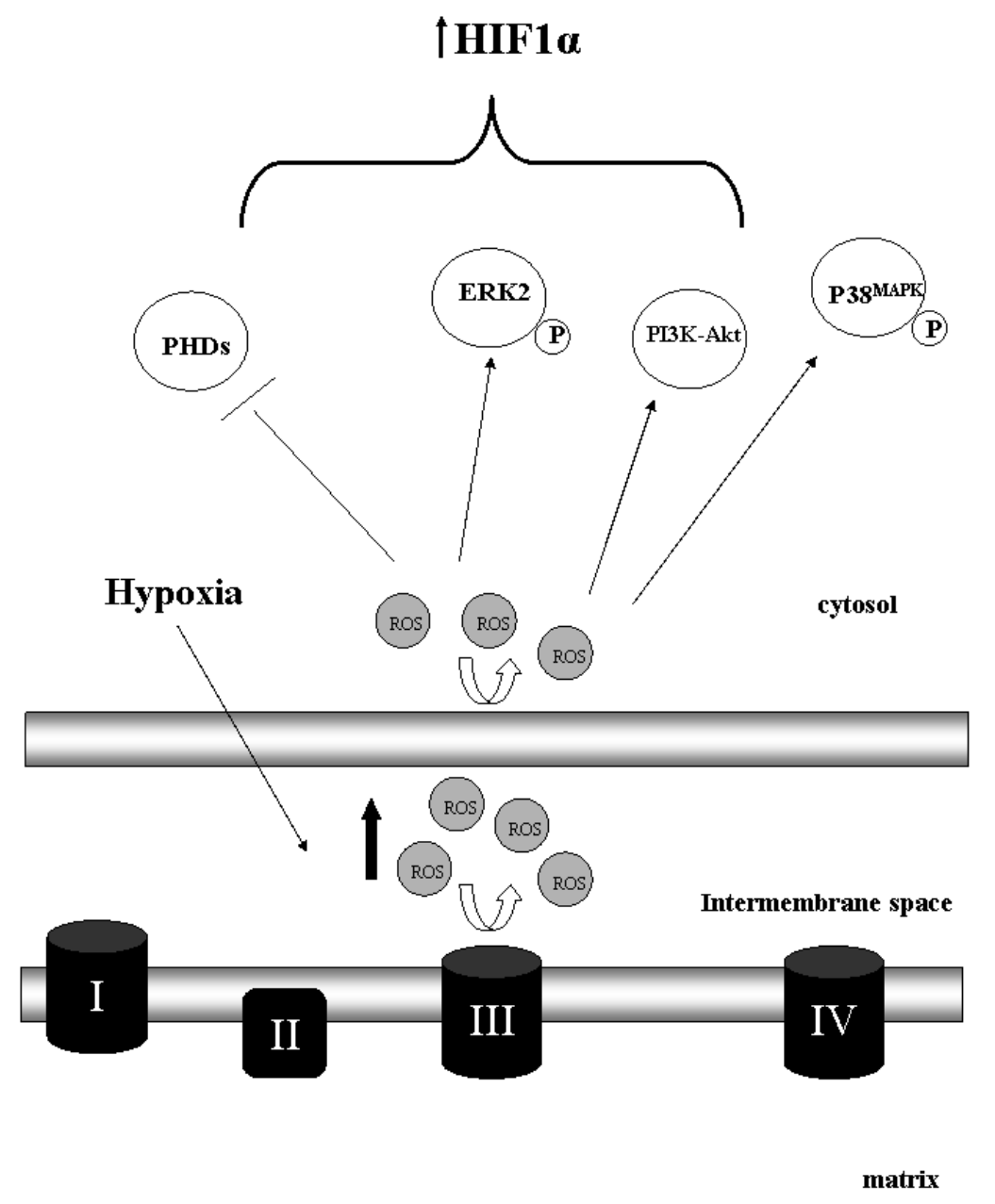

FIGURE 2. Schematic outline of the pathways that integrate ROS signaling and HIF-1 $\alpha$ pathway in hypoxic condition.

\section{BACE1 INDUCTION BY HYPOXIA-MEDIATED ROS}

Hypoxia increases BACE1 as well as the $\gamma$-secretase expression and activity, resulting in $\mathrm{A} \beta$ overproduction, as has been shown in vitro as well as in AD transgenic mice[49,50,51,52]. HIF-1 $\alpha$ binds to the BACE1 promoter and regulates its gene expression[50]. Of note, acute ischemia up-regulates BACE1 activity also through the impaired degradation of BACE1 mediated by the decreased levels of GGA3, a trafficking molecule that delivers BACE1 to the endosomal-lysosomal system[83].

We significantly extended these findings both in vivo and in vitro, showing that hypoxia up-regulates BACE1 mRNA expression in a biphasic manner, through two distinct mechanisms: (1) an early release of ROS from mitochondria and (2) a late activation of HIF-1 $\alpha$ [84].

Our hypothesis is that the early posthypoxic up-regulation of BACE1 depends on the generation of ROS mediated by the sudden interruption of the mitochondrial electron transport chain. The involvement of ROS released by mitochondria was confirmed by complete protection exerted by rotenone and diphenyl-phenylen iodonium, compounds that affect complex I of the mitochondrial electron transport chain $[85,86]$.The later expression of BACE1 is caused by HIF-1 $\alpha$ activation.

Thus, contrary to other reports[49,50], in our experimental conditions, we did not detect an evident nuclear translocation of HIF-1 $\alpha$ within $12 \mathrm{~h}$ of hypoxia. In fact, silencing of HIF-1 $\alpha$ (able to block the late up-regulation of BACE1) did not prevent the early increase in BACE1 mRNA and protein levels (Fig. 3). 


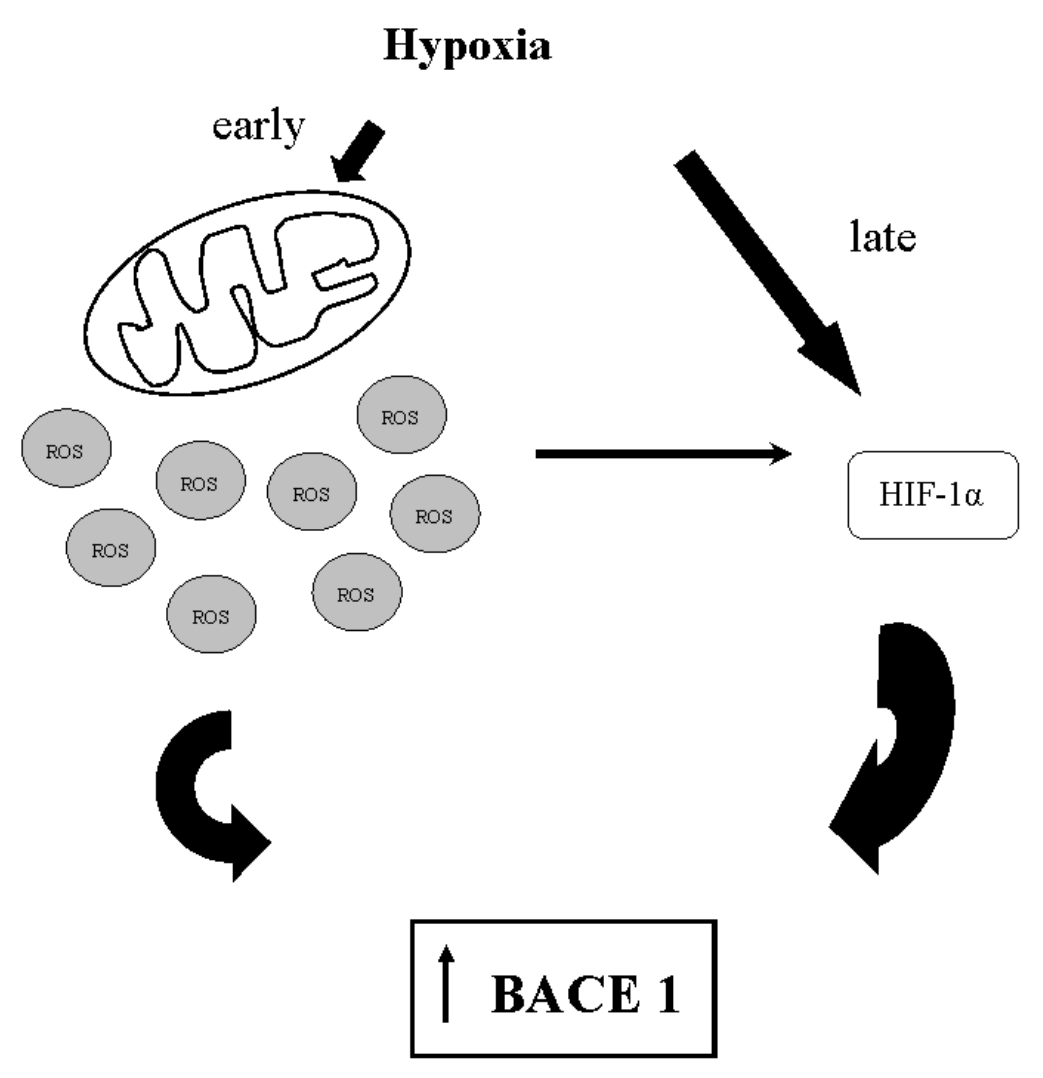

FIGURE 3. The early posthypoxic up-regulation of BACE1 depends on the generation of ROS mediated by the sudden interruption of the mitochondrial electron transport chain, while the later expression of BACE1 is caused by HIF-1 $\alpha$ activation.

In addition, the OS-mediated up-regulation of BACE1 is mediated by the c-jun N-terminal kinase (JNK) pathway, as demonstrated by the silencing of JNK isoforms 1 and 2.

Instead, this pathway is not active in the late phase of posthypoxic BACE1 increase, which depends on the activity of HIF-1 $\alpha$, as shown by the data obtained by HIF-1 $\alpha$ silencing.

It is well known that members of stress-activated protein kinase (SAPK), such as JNK, are markedly up-regulated in $\mathrm{AD}[87,88,89]$ and are activated by a variety of stress signals, including OS[90,91,92].

The early posthypoxic up-regulation of BACE1 recapitulates the cascade of events induced by oxidant agents and HNE in cells and in animal models. We have proposed that a sequence of events link ROS production, BACE1 up-regulation, and apoptotic cell death through an overproduction of $A \beta$. Initially, we have shown that oxidant agents and HNE significantly increase the expression, protein levels, and activity of BACE1 in $\mathrm{NT}_{2}$ neurons, without affecting the levels of APP[31,32]. These events are followed by an overproduction of $\mathrm{A} \beta$ peptides as well as by morphological signs of apoptotic cell death[34]. Finally, it has been observed that the up-regulation of BACE1 is modulated by the JNK pathway. Thus, there is a significant correlation of BACE1 activity with oxidative markers in sporadic AD brain tissue[35], in which a significant increase of BACE1 expression has been shown[36,37,38].

Moreover, we and others[39,93] have recently found that BACE1 expression is regulated by $\gamma$ secretase activity, providing evidence of a positive feedback loop between the $\gamma$ - and the $\beta$-secretase cleavages on APP. Interestingly, the expression of BACE1 is decreased by the activation of ERK1/2[94], which inhibits the $\gamma$-secretase[95].

The activity of the $\gamma$-secretase is modified by PS1 mutations as well as by molecules that interact directly with PS1[96,97,98]. OS is the only known factor able to augment the $\gamma$-secretase cleavage, increasing the expression of PS1, the catalytic subunit of the endoprotease. 
These findings suggest that the overproduction of $A \beta$, dependent on the up-regulation of BACE1 as well as of the $\gamma$-secretase as induced by OS, contributes to the pathogenesis of the common sporadic, lateonset form of $\mathrm{AD}$ (Fig. 4).

OXIDATIVE STRESS

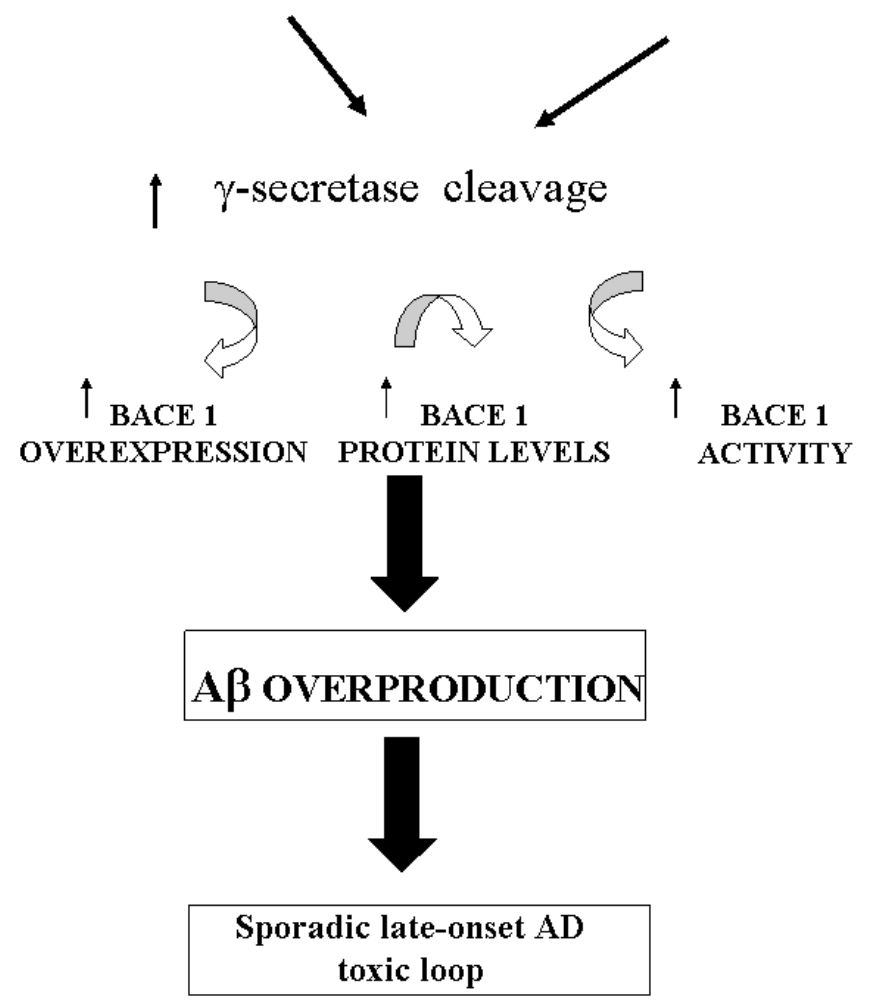

FIGURE 4. A sequence of the pathogenetic steps linking OS and/or hypoxiamediated mitochondrial ROS, $\gamma$-secretase up-regulation, BACE1 induction, and overproduction of $\mathrm{A} \beta$.

\section{ACKNOWLEDGMENTS}

This study was supported by the Italian Ministry of Health (MT), CARIGE Foundation (MT), and Regione Piemonte (ET).

\section{REFERENCES}

1. Yankner, B.A. (1996) Mechanisms of neuronal degeneration in Alzheimer's disease. Neuron 16, 921-932.

2. $\quad$ Citron, M., Oltersdorf, T., Haass, C., McConlogue, L., Hung, A.Y., Seubert, P., Vigo-Pelfrey, C., Lieberburg, I., and Selkoe, D.J. (1992) Mutation of the beta-amyloid precursor protein in familial Alzheimer's disease increases betaprotein production. Nature 360, 672-674.

3. Lemere, C.A., Lopera, F., Kosik, K.S., Lendon, C.L., Ossa, J., Saido, T.C., Yamaguchi, H., Ruiz, A., Martinez, A., Madrigal, L., Hincapie, L., Arango, J.C., Anthony, D.C., Koo, E.H., Goate, A.M., Selkoe, D.J., and Arango, J.C. (1996) The E280A presenilin 1 Alzheimer mutation produces increased A beta 42 deposition and severe cerebellar pathology. Nat. Med. 2, 1146-1150.

4. Citron, M., Westaway, D., Xia, W., Carlson, G., Diehl, T., Levesque, G., Johnson-Wood, K., Lee, M., Seubert, P., 
Davis, A., Kholodenko, D., Motter, R., Sherrington, R., Perry, B., Yao, H., Strome, R., Lieberburg, I., Rommens, J., Kim, S., Schenk, D., Fraser, P., St. George Hyslop, P., and Selkoe, D.J. (1997) Mutant presenilins of Alzheimer's disease increase production of 42-residue amyloid beta-protein in both transfected cells and transgenic mice. Nat. Med. 3, 67-72.

5. Tahirovic, I., Sofic, E., Sapcanin, A., Gavrankapetanovic, I., Bach-Rojecky, L., Salkovic-Petrisic, M., Lackovic, Z., Hoyer, S., and Riederer, P. (2007) Brain antioxidant capacity in rat models of betacytotoxic-induced experimental sporadic Alzheimer's disease and diabetes mellitus. J. Neural Transm. Suppl. 72, 235-240.

6. Schaeffer, E.L. and Gattaz, W.F. (2008) Cholinergic and glutamatergic alterations beginning at the early stages of Alzheimer disease: participation of the phospholipase A2 enzyme. Psychopharmacology (Berl.) 198, 1-27.

7. Ferreiro, E., Resende, R., Costa, R., Oliveira, C.R., and Pereira, C.M. (2006) An endoplasmic reticulum-specific apoptotic pathway is involved in prion and amyloid-beta peptides neurotoxicity. Neurobiol. Dis. 23, 669-678.

8. Mattson, M.P. (2002) Oxidative stress, perturbed calcium homeostasis, and immune dysfunction in Alzheimer's disease. J. Neurovirol. 8, 539-550.

9. de la Torre, J.C. (2008) Alzheimer's disease prevalence can be lowered with non-invasive testing. J. Alzheimers Dis. 14, 353-359.

10. Barja, G. (2004) Free radicals and aging. Trends Neurosci. 27, 595-600.

11. Harman, D. (1992) Free radical theory of aging. Mutat. Res. 275, 257-266.

12. Mattson, M.P., Chan, S.L., and Duan, W. (2002) Modification of brain aging and neurodegenerative disorders by genes, diet, and behavior. Physiol. Rev. 82, 637-672.

13. Floyd, R.A. and Hensley, K. (2002) Oxidative stress in brain aging. Implications for therapeutics of neurodegenerative diseases. Neurobiol. Aging 23, 795-807.

14. Harkany, T., Abrahám, I., Kónya, C., Nyakas, C., Zarándi, M., Penke, B., and Luiten, P.G. (2000) Mechanisms of beta-amyloid neurotoxicity: perspectives of pharmacotherapy. Rev. Neurosci. 11, 329-382.

15. Mattson, M.P. (2004) Pathways towards and away from Alzheimer's disease. Nature 430, 631-639.

16. Zhu, X., Raina, A.K., Perry, G., and Smith, M.A. (2004) Alzheimer's disease: the two-hit hypothesis. Lancet Neurol. 3, 219-226.

17. Paola, D., Domenicotti, C., Nitti, M., Vitali, A., Borghi, R., Cottalasso, D., Zaccheo, D., Odetti, P., Strocchi, P., Marinari, U.M., Tabaton, M., and Pronzato, M.A. (2000) Oxidative stress induces increase in intracellular amyloid beta-protein production and selective activation of betaI and betaII PKCs in NT2 cells. Biochem. Biophys. Res. Commun. 268, 642-646.

18. Misonou, H., Morishima-Kawashima, M., and Ihara, Y. (2000) Oxidative stress induces intracellular accumulation of amyloid beta-protein (Abeta) in human neuroblastoma cells. Biochemistry 39, 6951-6959.

19. Atwood, C.S., Obrenovich, M.E., Liu, T., Chan, H., Perry, G., Smith, M.A., and Martins, R.N. (2003) Amyloid-beta: a chameleon walking in two worlds: a review of the trophic and toxic properties of amyloid-beta. Brain Res. Brain Res. Rev. 43, 1-16.

20. Murray, I.V., Liu, L., Komatsu, H., Uryu, K., Xiao, G., Lawson, J.A., and Axelsen, P.H. (2007) Membrane-mediated amyloidogenesis and the promotion of oxidative lipid damage by amyloid beta proteins. J. Biol. Chem. 282, 9335-9345.

21. Tong, Y., Zhou, W., Fung, V., Christensen, M.A., Qing, H., Sun, X., and Song, W. (2005) Oxidative stress potentiates BACE1 gene expression and Abeta generation. J. Neural Transm. 112, 455-469.

Huang, X., Cuajungco, M.P., Atwood, C.S., Hartshorn, M.A., Tyndall, J.D., Hanson, G.R., Stokes, K.C., Leopold, M., Multhaup, G., Goldstein, L.E., Scarpa, R.C., Saunders, A.J., Lim, J., Moir, R.D., Glabe, C., Bowden, E.F., Masters, C.L., Fairlie, D.P., Tanzi, R.E., and Bush, A.I. (1999) Cu(II) potentiation of Alzheimer abeta neurotoxicity. Correlation with cell-free hydrogen peroxide production and metal reduction. J. Biol. Chem. 274, 37111-37116.

23. Barnham, K.J., Haeffner, F., Ciccotosto, G.D., Curtain, C.C., Tew, D., Mavros, C., Beyreuther, K., Carrington, D., Masters, C.L., Cherny, R.A., Cappai, R., and Bush, A.I. (2004) Tyrosine gated electron transfer is key to the toxic mechanism of Alzheimer's disease beta-amyloid. FASEB J. 18, 1427-1429.

24. Yatin, S.M., Varadarajan, S., Link, C.D., and Butterfield, D.A. (1999) In vitro and in vivo oxidative stress associated with Alzheimer's amyloid beta-peptide 1-42. Neurobiol. Aging 20, 325-330.

25. Crouch, P.J., Barnham, K.J., Duce, J.A., Blake, RE., Masters, C.L., and Trounce, I.A. (2006) Copper-dependent inhibition of cytochrome c oxidase by Abeta(1-42) requires reduced methionine at residue 35 of the Abeta peptide. $J$. Neurochem. 99, 226-236.

26. Mattson, M.P. (1997) Cellular actions of beta-amyloid precursor protein and its soluble and fibrillogenic derivatives. Physiol. Rev. 77, 1081-1132.

27. Bezprozvanny, I. and Mattson, M.P. (2008) Neuronal calcium mishandling and the pathogenesis of Alzheimer's disease. Trends Neurosci. 31, 454-463.

28. Cheng, S.Y. and Trombetta, L.D. (2004) The induction of amyloid precursor protein and alpha-synuclein in rat hippocampal astrocytes by diethyldithiocarbamate and copper with or without glutathione. Toxicol. Lett. 146, 139149.

29. Patil, S., Sheng, L., Masserang, A., and Chan, C. (2006) Palmitic acid-treated astrocytes induce BACE1 upregulation and accumulation of C-terminal fragment of APP in primary cortical neurons. Neurosci. Lett. 406, 55-59.

30. Frederikse, P.H., Garland, D., Zigler, J.S., Jr., and Piatigorsky, J. (1996) Oxidative stress increases production of betaamyloid precursor protein and beta-amyloid (Abeta) in mammalian lenses, and Abeta has toxic effects on lens 
epithelial cells. J. Biol. Chem. 271, 10169-10174.

31. Tamagno, E., Bardini, P., Abbili, A., Vitali, A., Borghi, R., Zaccheo, D., Pronzato, M.A., Danni, O., Smith, M.A., Perry, G., and Tabaton, M. (2002) Oxidative stress increases expression and activity of BACE in NT2 neurons. Neurobiol. Dis. 10, 279-288.

32. Tamagno, E., Guglielmotto, M., Bardini, P., Santoro, G., Davit, A., Di Simone, D., Danni, O., and Tabaton, M. (2003) Dehydroepiandrosterone reduces expression and activity of BACE in NT2 neurons exposed to oxidative stress. Neurobiol. Dis. 14, 291-301.

33. Kao, S.C., Krichevsky, A.M., Kosik, K.S., and Tsai, L.H. (2004) BACE1 suppression by RNA interference in primary cortical neurons. J. Biol. Chem. 279, 1942-1949.

34. Tamagno, E., Parola, M., Bardini, P., Piccini, A., Borghi, R., Guglielmotto, M., Santoro, G., Davit, A., Danni, O., Smith, M.A., Perry, G., and Tabaton, M. (2005) Beta-site APP cleaving enzyme up-regulation induced by 4hydroxynonenal is mediated by stress-activated protein kinases pathways. J. Neurochem. 92, 628-636.

35. Borghi, R., Patriarca, S., Traverso, N., Piccini, A., Storace, D., Garuti, A., Cirmena, G., Odetti, P., and Tabaton, M. (2007) The increased activity of BACE1 correlates with oxidative stress in Alzheimer's disease. Neurobiol. Aging 28, 1009-1014.

36. Fukumoto, H., Cheung, B.S., Hyman, B.T., and Irizarry, M.C. (2002) Beta-secretase protein and activity are increased in the neocortex in Alzheimer disease. Arch. Neurol. 59, 1381-1389.

37. Holsinger, R.M., McLean, C.A., Beyreuther, K., Masters, C.L., and Evin, G. (2002) Increased expression of the amyloid precursor beta-secretase in Alzheimer's disease. Ann. Neurol. 51, 783-786.

38. Yang, L.B., Lindholm, K., Yan, R., Citron, M., Xia, W., Yang, X.L., Beach, T., Sue, L., Wong, P., Price, D., Li, R., and Shen, Y. (2003) Elevated beta-secretase expression and enzymatic activity detected in sporadic Alzheimer disease. Nat. Med.9, 3-4.

39. Tamagno, E., Guglielmotto, M., Aragno, M., Borghi, R., Autelli, R., Giliberto, L., Muraca, G., Danni, O., Zhu, X., Smith, M.A., Perry, G., Jo, D.G., Mattson, M.P., and Tabaton, M. (2008) Oxidative stress activates a positive feedback between the gamma- and beta-secretase cleavages of the beta-amyloid precursor protein. J. Neurochem. 104, 683-695.

40. Sharp, F.R. and Bernaudin, M. (2004) HIF1 and oxygen sensing in the brain. Nat. Rev. Neurosci. 5, 437-448.

41. Wang, G.L. and Semenza, G.L. (1995) Purification and characterization of hypoxia-inducible factor 1. J. Biol. Chem. 270, 1230-1237.

42. Wang, G.L., Jiang, B.H., Rue, E.A., and Semenza, G.L. (1995) Hypoxia-inducible factor 1 is a basic-helix-loop-helixPAS heterodimer regulated by cellular O2 tension. Proc. Natl. Acad. Sci. U. S. A. 92, 5510-5514.

43. Sowter, H.M., Raval, R.R., Moore, J.W., Ratcliffe, P.J., and Harris, A.L. (2003) Predominant role of hypoxiainducible transcription factor (Hif)-1alpha versus Hif-2alpha in regulation of the transcriptional response to hypoxia. Cancer Res. 63, 6130-6134.

44. Huang, L.E. and Bunn, H.F. (2003) Hypoxia-inducible factor and its biomedical relevance. J. Biol. Chem. 278, 19575-19578.

45. Koistinaho, M. and Koistinaho, J. (2005) Interactions between Alzheimer's disease and cerebral ischemia--focus on inflammation. Brain Res. Brain Res. Rev. 48, 240-250.

46. Schneider, J.A., Wilson, R.S., Cochran, E.J., Bienias, J.L., Arnold, S.E., Evans, D.A., and Bennett, D.A. (2003) Relation of cerebral infarctions to dementia and cognitive function in older persons. Neurology 60, 1082-1088.

47. Vermeer, S.E., Prins, N.D., den Heijer, T., Hofman, A., Koudstaal, P.J., and Breteler, M.M. (2003) Silent brain infarcts and the risk of dementia and cognitive decline. N. Engl. J. Med. 348, 1215-1222.

48. Jellinger, K.A. (2003) The pathology of "vascular dementia": a critical update. J. Alzheimers Dis. 14, $107-123$.

49. Sun, X., He, G., Qing, H., Zhou, W., Dobie, F., Cai, F., Staufenbiel, M., Huang, L.E., and Song, W. (2006) Hypoxia facilitates Alzheimer's disease pathogenesis by up-regulating BACE1 gene expression. Proc. Natl. Acad. Sci. U. S. A. 103, 18727-18732.

50. Zhang, X., Zhou, K., Wang, R., Cui, J., Lipton, S.A., Liao, F.F., Xu, H., and Zhang, Y.W. (2007) Hypoxia-inducible factor 1alpha (HIF-1alpha)-mediated hypoxia increases BACE1 expression and beta-amyloid generation. J. Biol. Chem. 282, 10873-10880.

51. Wang, R., Zhang, Y.W., Zhang, X., Liu, R., Zhang, X., Hong, S., Xia, K., Xia, J., Zhang, Z., and Xu, H. (2006) Transcriptional regulation of APH-1A and increased gamma-secretase cleavage of APP and Notch by HIF-1 and hypoxia. FASEB J. 20, 1275-1277.

52. Li, L., Zhang, X., Yang, D., Luo, G., Chen, S., and Le, W. (2009) Hypoxia increases Abeta generation by altering beta- and gamma-cleavage of APP. Neurobiol. Aging 30(7), 1091-1098.

53. Hu, Y. and Fortini, M.E. (2003) Different cofactor activities in gamma-secretase assembly: evidence for a nicastrinAph-1 subcomplex. J. Cell Biol. 161, 685-690.

54. Kim, S.H., Ikeuchi, T., Yu, C., and Sisodia, S.S. (2003) Regulated hyperaccumulation of presenilin-1 and the "gamma-secretase" complex. Evidence for differential intramembranous processing of transmembrane substrates. $J$. Biol. Chem. 278, 33992-34002.

55. Chandel, N.S., Maltepe, E., Goldwasser, E., Mathieu, C.E., Simon, M.C., and Schumacker, P.T. (1998) Mitochondrial reactive oxygen species trigger hypoxia-induced transcription. Proc. Natl. Acad. Sci. U. S. A. 95, 11715-11720.

56. Mansfield, K.D., Simon, M.C., and Keith, B. (2004) Hypoxic reduction in cellular glutathione levels requires 
mitochondrial reactive oxygen species. J. Appl. Physiol. 97, 1358-1366.

57. Guzy, R.D., Hoyos, B., Robin, E., Chen, H., Liu, L., Mansfield, K.D., Simon, M.C., Hammerling, U., and Schumacker, P.T. (2005) Mitochondrial complex III is required for hypoxia-induced ROS production and cellular oxygen sensing. Cell Metab. 1, 401-408.

58. Mansfield, K.D., Guzy, R.D., Pan, Y., Young, R.M., Cash, T.P., Schumacker, P.T., and Simon, M.C. (2005) Mitochondrial dysfunction resulting from loss of cytochrome c impairs cellular oxygen sensing and hypoxic HIFalpha activation. Cell Metab. 1, 393-399.

59. Dirmeier, R., O'Brien, K.M., Engle, M., Dodd, A., Spears, E., and Poyton, R.O. (2002) Exposure of yeast cells to anoxia induces transient oxidative stress. Implications for the induction of hypoxic genes. J. Biol. Chem. 277, 3477334784.

60. Kummer, W. and Acker, H. (1995) Immunohistochemical demonstration of four subunits of neutrophil NAD(P)H oxidase in type I cells of carotid body. J. Appl. Physiol. 78, 1904-1909.

61. Marshall, C., Mamary, A.J., Verhoeven, A.J., and Marshall, B.E. (1996) Pulmonary artery NADPH-oxidase is activated in hypoxic pulmonary vasoconstriction. Am. J. Respir. Cell Mol. Biol. 15, 633-644.

62. Wenger, R.H., Marti, H.H., Schuerer-Maly, C.C., Kvietikova, I., Bauer, C., Gassmann, M., and Maly, F.E. (1996) Hypoxic induction of gene expression in chronic granulomatous disease-derived B-cell lines: oxygen sensing is independent of the cytochrome b558-containing nicotinamide adenine dinucleotide phosphate oxidase. Blood 87, $756-761$.

63. Turrens, J.F. (2003) Mitochondrial formation of reactive oxygen species. J. Physiol. 552(Pt 2), 335-344.

64. Klimova, T. and Chandel, N.S. (2008) Mitochondrial complex III regulates hypoxic activation of HIF. Cell Death Differ. 15, 660-666.

65. Bell, E.L., Klimova, T.A., Eisenbart, J., Moraes, C.T., Murphy, M.P., Budinger, G.R., and Chandel, N.S. (2007) The Qo site of the mitochondrial complex III is required for the transduction of hypoxic signaling via reactive oxygen species production. J. Cell Biol. 177, 1029-1036.

66. Aminova, L.R., Siddiq, A., and Ratan, R.R. (2008) Antioxidants, HIF prolyl hydroxylase inhibitors or short interfering RNAs to BNIP3 or PUMA, can prevent prodeath effects of the transcriptional activator, HIF-1alpha, in a mouse hippocampal neuronal line. Antioxid. Redox Signal. 10, 1989-1998.

67. Hwang, K.Y., Oh, Y.T., Yoon, H., Lee, J., Kim, H., Choe, W., and Kang, I. (2008) Baicalein suppresses hypoxiainduced HIF-1alpha protein accumulation and activation through inhibition of reactive oxygen species and PI 3kinase/Akt pathway in BV2 murine microglial cells. Neurosci. Lett. 444, 264-269.

68. Gao, P., Zhang, H., Dinavahi, R., Li, F., Xiang, Y., Raman, V., Bhujwalla, Z.M., Felsher, D.W., Cheng, L., Pevsner, J., Lee, L.A., Semenza, G.L., and Dang, C.V. (2007) HIF-dependent antitumorigenic effect of antioxidants in vivo. Cancer Cell 12, 230-238.

69. Park, J.H., Kim, T.Y., Jong, H.S., Kim, T.Y., Chun, Y.S., Park, J.W., Lee, C.T., Jung, H.C., Kim, N.K., and Bang, Y.J. (2003) Gastric epithelial reactive oxygen species prevent normoxic degradation of hypoxia-inducible factor1alpha in gastric cancer cells. Clin. Cancer Res. 9, 433-440.

70. Pagé, E.L., Chan, D.A., Giaccia, A.J., Levine, M., and Richard, D.E. (2008) Hypoxia-inducible factor-1alpha stabilization in nonhypoxic conditions: role of oxidation and intracellular ascorbate depletion. Mol. Biol. Cell 19, 86-94.

71. Bruick, R.K. and McKnight, S.L. (2001) A conserved family of prolyl-4-hydroxylases that modify HIF. Science 294, 1337-1340.

72. $\quad$ Epstein, A.C., Gleadle, J.M., McNeill, L.A., Hewitson, K.S., O'Rourke, J., Mole, D.R., Mukherji, M., Metzen, E., Wilson, M.I., Dhanda, A., Tian, Y.M., Masson, N., Hamilton, D.L., Jaakkola, P., Barstead, R., Hodgkin, J., Maxwell, P.H., Pugh, C.W., Schofield, C.J., and Ratcliffe, P.J. (2001) C. elegans EGL-9 and mammalian homologs define a family of dioxygenases that regulate HIF by prolyl hydroxylation. Cell 107, 43-54.

73. Pan, Y., Mansfield, K.D., Bertozzi, C.C., Rudenko, V., Chan, D.A., Giaccia, A.J., and Simon, M.C. (2007) Multiple factors affecting cellular redox status and energy metabolism modulate hypoxia-inducible factor prolyl hydroxylase activity in vivo and in vitro. Mol. Cell. Biol. 27, 912-925.

74. Gerald, D., Berra, E., Frapart, Y.M., Chan, D.A., Giaccia, A.J., Mansuy, D., Pouysségur, J., Yaniv, M., and MechtaGrigoriou, F. (2004) JunD reduces tumor angiogenesis by protecting cells from oxidative stress. Cell 118, 781-794.

75. Pouysségur, J. and Mechta-Grigoriou, F. (2006) Redox regulation of the hypoxia-inducible factor. Biol. Chem. 387, 1337-1346.

76. Richard, D.E., Berra, E., Gothié, E., Roux, D., and Pouysségur, J. (1999) p42/p44 mitogen-activated protein kinases phosphorylate hypoxia-inducible factor 1alpha (HIF-1alpha) and enhance the transcriptional activity of HIF-1. J. Biol. Chem. 274, 32631-32637.

77. Mylonis, I., Chachami, G., Samiotaki, M., Panayotou, G., Paraskeva, E., Kalousi, A., Georgatsou, E., Bonanou, S., and Simos, G. (2006) Identification of MAPK phosphorylation sites and their role in the localization and activity of hypoxia-inducible factor-1alpha. J. Biol. Chem. 281, 33095-33106.

78. Emerling, B.M., Platanias, L.C., Black, E., Nebreda, A.R., Davis, R.J., and Chandel, N.S. (2005) Mitochondrial reactive oxygen species activation of p38 mitogen-activated protein kinase is required for hypoxia signaling. Mol. Cell. Biol. 25, 4853-4862.

79. Shaw, R.J. and Cantley, L.C. (2006) Ras, PI(3)K and mTOR signalling controls tumour cell growth. Nature 441, 424430. 
80. Zhou, Q., Liu, L.Z., Fu, B., Hu, X., Shi, X., Fang, J., and Jiang, B.H. (2007) Reactive oxygen species regulate insulininduced VEGF and HIF-1alpha expression through the activation of p70S6K1 in human prostate cancer cells. Carcinogenesis 28, 28-37.

81. Gao, N., Ding, M., Zheng, J.Z., Zhang, Z., Leonard, S.S., Liu, K.J., Shi, X., and Jiang, B.H. (2002) Vanadate-induced expression of hypoxia-inducible factor 1 alpha and vascular endothelial growth factor through phosphatidylinositol 3kinase/Akt pathway and reactive oxygen species. J. Biol. Chem. 277, 31963-31971.

82. Flügel, D., Görlach, A., Michiels, C., and Kietzmann, T. (2007) Glycogen synthase kinase 3 phosphorylates hypoxiainducible factor 1alpha and mediates its destabilization in a VHL-independent manner. Mol. Cell. Biol. 27, 32533265.

83. Tesco, G., Koh, Y.H., Kang, E.L., Cameron, A.N., Das, S., Sena-Esteves, M., Hiltunen, M., Yang, S.H., Zhong, Z., Shen, Y., Simpkins, J.W., and Tanzi, R.E. (2007) Depletion of GGA3 stabilizes BACE and enhances beta-secretase activity. Neuron 54, 721-737.

84. Guglielmotto, M., Aragno, M., Autelli, R., Giliberto, L., Novo, E., Colombatto, S., Danni, O., Parola, M., Smith, M.A., Perry, G., Tamagno, E., and Tabaton, M. (2009) The up-regulation of BACE1 mediated by hypoxia and ischemic injury: role of oxidative stress and HIF1alpha. J. Neurochem. 108, 1045-1056.

85. Höglinger, G.U., Lannuzel, A., Khondiker, M.E., Michel, P.P., Duyckaerts, C., Féger, J., Champy, P., Prigent, A., Medja, F., Lombes, A., Oertel, W.H., Ruberg, M., and Hirsch, E.C. (2005) The mitochondrial complex I inhibitor rotenone triggers a cerebral tauopathy. J. Neurochem. 95, 930-939.

86. Li, Y. and Trush, M.A. (1998) Diphenyleneiodonium, an NAD(P)H oxidase inhibitor, also potently inhibits mitochondrial reactive oxygen species production. Biochem. Biophys. Res. Commun. 253, 295-299.

87. Zhu, X., Ogawa, O., Wang, Y., Perry, G., and Smith, M.A. (2003) JKK1, an upstream activator of JNK/SAPK, is activated in Alzheimer's disease. J. Neurochem. 85, 87-93.

88. Zhu, X., Raina, A.K., Lee, H.G., Chao, M., Nunomura, A., Tabaton, M., Petersen, R.B., Perry, G., and Smith, M.A. (2003) Oxidative stress and neuronal adaptation in Alzheimer disease: the role of SAPK pathways. Antioxid. Redox Signal. 5, 571-576.

89. Lagalwar, S., Guillozet-Bongaarts, A.L., Berry, R.W., and Binder, L.I. (2006) Formation of phospho-SAPK/JNK granules in the hippocampus is an early event in Alzheimer disease. J. Neuropathol. Exp. Neurol. 65, 455-464.

90. Kanzawa, T., Iwado, E., Aoki, H., Iwamaru, A., Hollingsworth, E.F., Sawaya, R., Kondo, S., and Kondo, Y. (2006) Ionizing radiation induces apoptosis and inhibits neuronal differentiation in rat neural stem cells via the c-Jun NH2terminal kinase (JNK) pathway. Oncogene 25, 3638-3648.

91. Pugazhenthi, S., Phansalkar, K., Audesirk, G., West, A., and Cabell, L. (2006) Differential regulation of c-jun and CREB by acrolein and 4-hydroxynonenal. Free Radic. Biol. Med. 40, 21-34.

92. Zhang, Q.G., Wu, D.N., Han, D., and Zhang, G.Y. (2007) Critical role of PTEN in the coupling between PI3K/Akt and JNK1/2 signaling in ischemic brain injury. FEBS Lett. 581, 495-505.

93. Jo, D.G., Arumugam, T.V., Woo, H.N., Park, J.S., Tang, S.C., Mughal, M., Hyun, D.H., Park, J.H., Choi, Y.H., Gwon, A.R., Camandola, S., Cheng, A., Cai, H., Song, W., Markesbery, W.R., and Mattson, M.P. (2008) Evidence that gamma-secretase mediates oxidative stress-induced beta-secretase expression in Alzheimer's disease. Neurobiol. Aging [Epub ahead of print]

94. Tamagno, E., Guglielmotto, M., Giliberto, L., Vitali, A., Borghi, R., Autelli, R., Dann, O., and Tabaton, M. (2008) JNK and ERK1/2 pathways have a dual opposite effect on the expression of BACE1. Neurobiol. Aging [Epub ahead of print]

95. Kim, S.K., Park, H.J., Hong, H.S., Baik, E.J., Jung, M.W., and Mook-Jung, I. (2006) ERK1/2 is an endogenous negative regulator of the gamma-secretase activity. FASEB J. 20, 157-159.

96. Beher, D., Clarke, E.E., Wrigley, J.D., Martin, A.C., Nadin, A., Churcher, I., and Shearman, M.S. (2004) Selected non-steroidal anti-inflammatory drugs and their derivatives target gamma-secretase at a novel site. Evidence for an allosteric mechanism. J. Biol. Chem. 279, 43419-43426.

97. Matsuda, S., Giliberto, L., Matsuda, Y., Davies, P., McGowan, E., Pickford, F., Ghiso, J., Frangione, B., and D'Adamio, L. (2005) The familial dementia BRI2 gene binds the Alzheimer gene amyloid-beta precursor protein and inhibits amyloid-beta production. J. Biol. Chem. 280, 28912-28916.

98. Cai, D., Netzer, W.J., Zhong, M., Lin, Y., Du, G., Frohman, M., Foster, D.A., Sisodia, S.S., Xu, H., Gorelick, F.S., and Greengard, P. (2006) Presenilin-1 uses phospholipase D1 as a negative regulator of beta-amyloid formation. Proc. Natl. Acad. Sci. U. S. A. 103, 1941-1946.

\section{This article should be cited as follows:}

Guglielmotto, M., Tamagno, E., and Danni, O. (2009) Oxidative stress and hypoxia contribute to Alzheimer's disease pathogenesis: two sides of the same coin. TheScientificWorldJOURNAL 9, 781-791. DOI 10.1100/tsw.2009.93. 


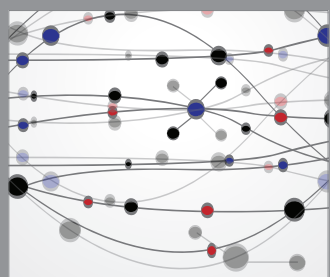

The Scientific World Journal
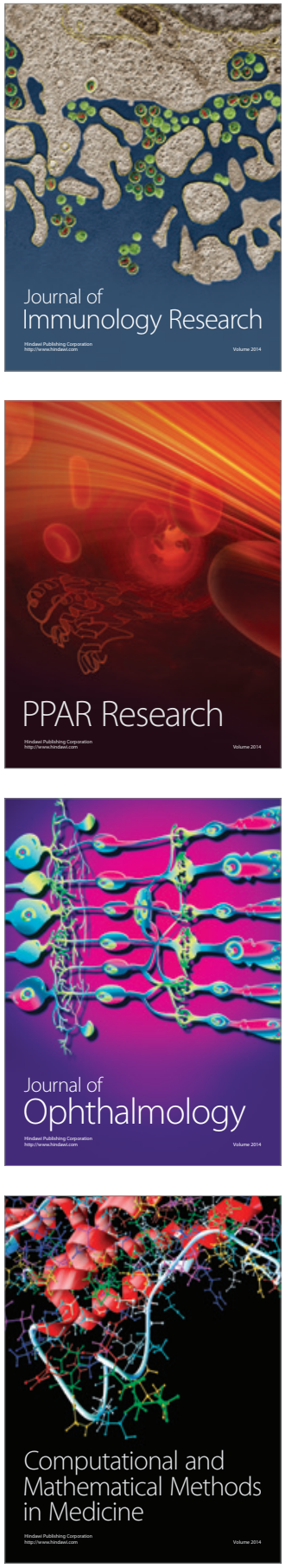

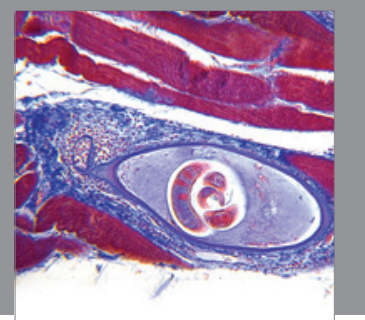

Gastroenterology

Research and Practice
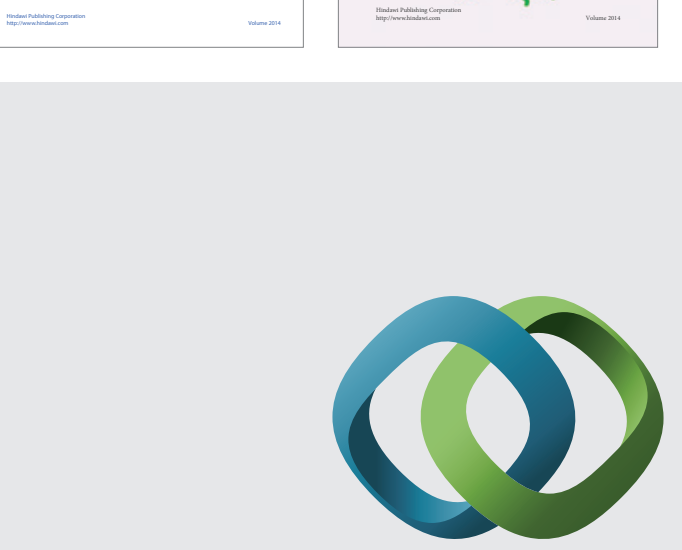

\section{Hindawi}

Submit your manuscripts at

http://www.hindawi.com
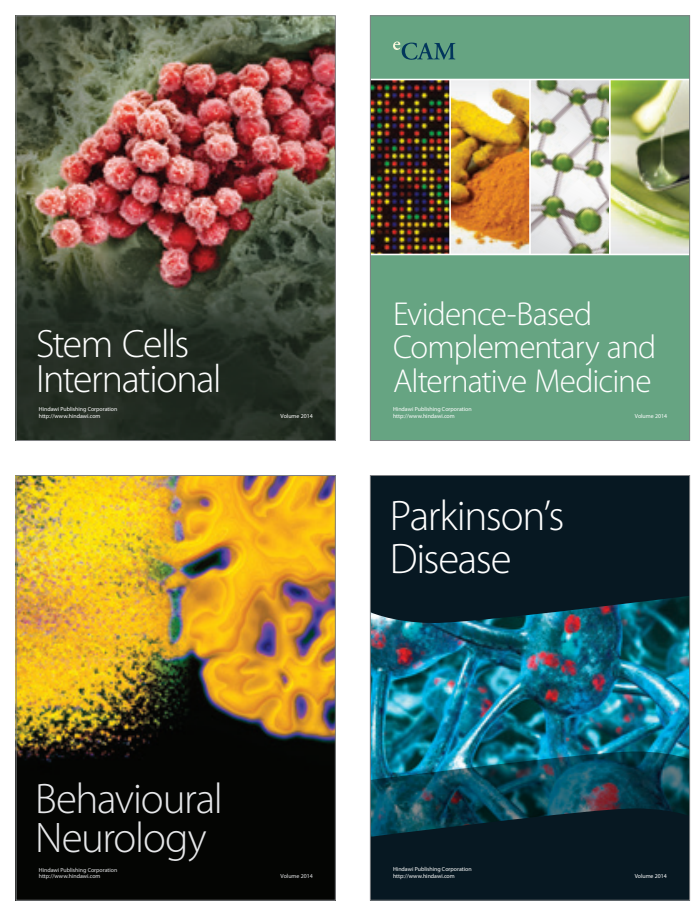

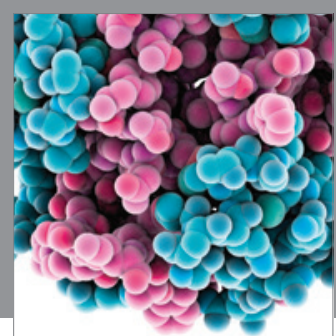

Journal of
Diabetes Research

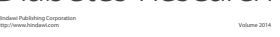

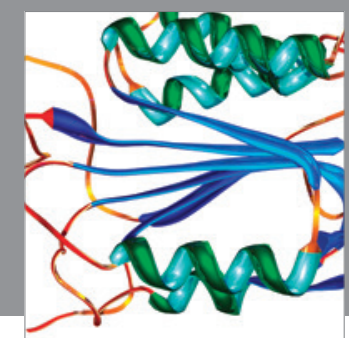

Disease Markers
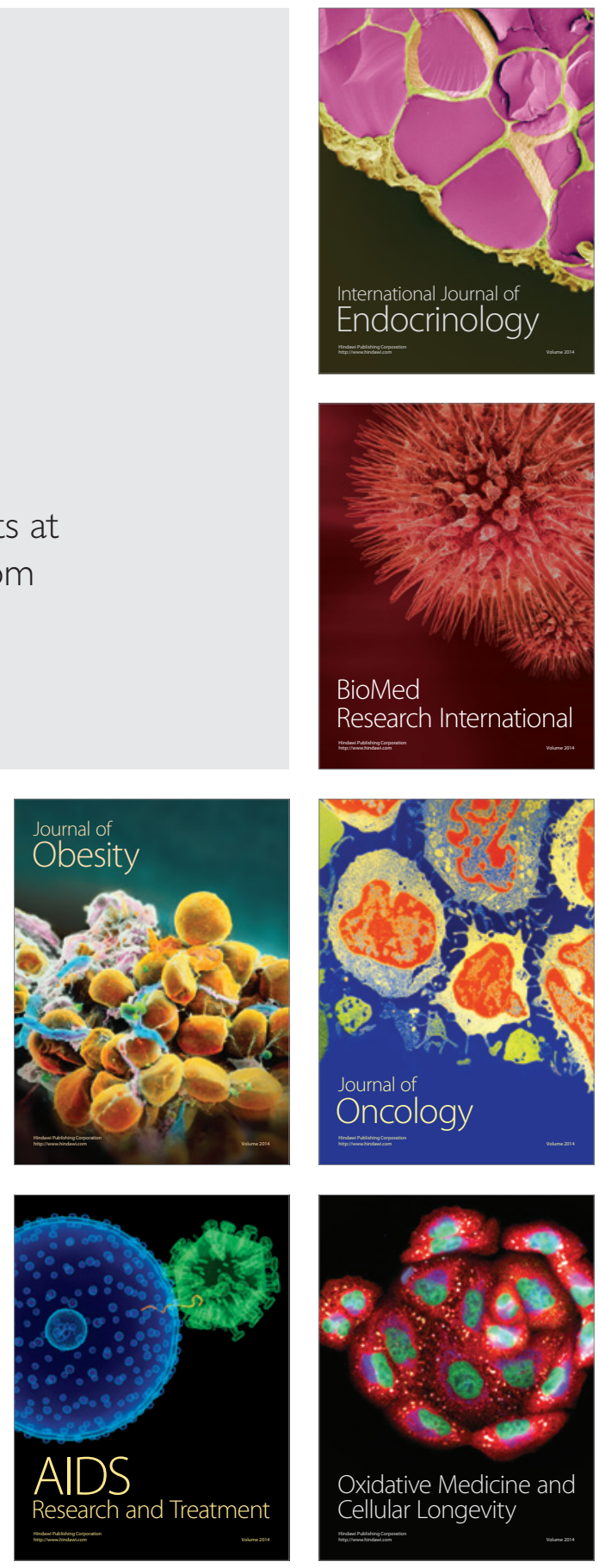